\title{
Ecological effects of small dams on benthic macroinvertebrate communities of mountain streams (Córdoba, Argentina)
}

\author{
Romina E. Principe* \\ Departamento de Ciencias Naturales, Universidad Nacional de Río Cuarto (UNRC), Ruta 36 Km 601, X5804BYA, \\ Río Cuarto, Córdoba, Argentina
}

Received 1st October 2009; Accepted 21 January 2010

\begin{abstract}
We assessed the effect of small dams on stream habitats and on the structure and function of benthic macroinvertebrate communities in mountain streams of Córdoba, Argentina. Two streams with small dams (impacted streams) and two streams without dams (control streams) from the Carcarañá River upper sub-basin were selected. Dominant hydraulic units were identified and benthic samples were collected in each of these units during high and low water periods. According to this study small dams may have impact on the function and structure of the invertebrate community, though hydraulic habitats would not be affected. Fourteen hydraulic units were found and changes due to dams were not observed as assessed by the detrended correspondence analysis. The canonical correspondence analysis grouped samples mainly in relation to hydraulic habitats whereas TWINSPAN grouped samples according to the presence of dams. Nested ANOVAs showed changes in richness and diversity, in the abundance of filterers and shredders and in the abundance of certain species. Small dams generate quite small reservoirs and their permeability may be greater than those of large dams. The behaviour of macroinvertebrate populations in drift and colonization processes, the continuity of the riparian structure and the discharge of planktonic algae downstream the dams may be some factors determining the ecological changes produced by small impoundments.
\end{abstract}

Key words: Small impoundments / stream benthos / fluvial habitats / downstream effects / impact

\section{Introduction}

River regulation is one of the most widespread human impacts on lotic ecosystems with profound effects on these environments. Dams generate a variety of modifications in riverine systems: they alter the downstream flow and movement of sediments modifying biogeochemical cycles and the structure of aquatic and riparian habitats, they modify water temperature affecting bioenergetics of organisms and they constitute barriers to the movement of organisms and nutrients impeding biotic interchange (Baxter, 1977; Ward and Stanford, 1979; Ward, 1982; Brittain and L'Abée-Lund, 1995; Poff and Hart, 2002). These alterations have significant ecological effects at different temporal and spatial scales and affect the natural connectivity of lotic ecosystems (Allan and Castillo, 2007).

Impoundments vary tremendously in size, purpose and management and these factors have influence on the degree of the ecological disturbance (Poff and Hart, 2002; Allan and Castillo, 2007). Downstream effects of dams

\footnotetext{
* Corresponding author: principe.romina@gmail.com
}

greatly depend on the geographic location, the environment, substrate type, and water and sediment discharge (Brandt, 2000). The generalizations in relation to the effect of river regulation are mainly based on research dealing with the effect of large dams $(>15-20 \mathrm{~m}$ according to international standards) in middle reaches of temperate streams (Ward and Stanford, 1979; Ward, 1982; Hart et al., 2002). Less comprehensive data are available for regulated rivers at high and equatorial latitudes (but see Benstead et al., 1999; Bredenhand and Samways, 2009; Zeilhofera and de Moura, 2009) and there are also few studies on the effects of small impoundments of $<10 \mathrm{~m}$ height (but see Sharma et al., 2005; Ambers, 2007; Skalak et al., 2009).

Although the adverse effects of large impoundments are relatively well documented, it is unclear whether the current information on large dam effects is applicable to smaller dams. As dams vary in magnitude and hence in storage volumes, impacts of different sized dams can not be generalized without performing strict comparisons. At present, little empirical data are available to allow meaningful generalizations (Poff and Hart, 2002). Then, a better 
understanding of the effects of dams, particularly across a range of dam sizes, is needed to guide management decisions and maximize the effectiveness of river restoration projects. Some studies have evaluated the ecological effects of small dams $(<10 \mathrm{~m}$ height $)$ to be able to predict how streams and watersheds were likely to respond to the potential removal of these dams (Ambers, 2007; Maloney et al., 2008; Skalak et al., 2009). Dam removal has become an increasingly practiced form of restoration, which has been proposed as a method to restore connectivity and to improve fluvial health, but it has been mainly applied to small and obsolete dams with poor structural conditions (American Rivers, Friends of the Heart and Trout Unlimited, 1999). Since most of the dams on the Planet are relatively small structures, the evaluation of their environmental impacts is critical to the issue of dam removal (Poff and Hart, 2002).

Very small dams, such us 2-m-high diversion and runof-river mill dams, are likely to have relatively limited effects on peak flows or downstream sediment regime by virtue of their small storage volume, though they may still reduce downstream flows at low discharge and prevent upstream movement of fishes and invertebrates (Poff and Hart, 2002; Saila et al., 2005; Lucas et al., 2008) according to the permeability of the barrier (Reiser and Peacock, 1985). Barriers to fluvial migration occur through the interaction of topography, human structures, and the timing of precipitation and high stream flows (Meixler and Bain, 2003). Potential barriers to upstream migration include natural (waterfalls, cascades and debris dams) and artificial (culverts and dams) structures. Despite the small size of some dams they may restrict the connectivity of the fluvial system (Poff and Hart, 2002).

In mountain streams of Córdoba province and in other streams of the central region of Argentina, dams of different size and purpose have been constructed. As a result, many streams and rivers of this region have altered their natural flows due to the presence of either large ( $>30 \mathrm{~m}$ height) or very small dams $(<5 \mathrm{~m}$ height). Although the effect of large dams on invertebrate fauna has already been studied in the Carcarañá river basin and in other lotic systems of the region (Corigliano, 1994; Vallania et al., 1998; Vallania and Corigliano, 2007), studies on the impact of small dams are still lacking. These small dams are widely spread in mountain streams of the region and their main function is to generate recreational environments since they retain water and fine sediments that level the streambed which is naturally constituted by cobbles and boulders. Therefore, small dams outline swimming areas that are mainly used in summer by tourists.

In this study, we assessed the effect of small dams on stream habitats and on the structure and function of benthic macroinvertebrate communities in mountain streams. Instream habitat units were assessed in dammed and undammed stream reaches and changes in habitats downstream the dams were also analyzed. Variations in structural and functional community attributes and taxonomic composition of macroinvertebrate assemblages were evaluated. The evaluation of these dam effects become essential to predict potential impacts of new planned impoundments and to predict responses of the system if dam removal is performed as a restoration practice.

\section{Materials and methods}

\section{Study area}

The study was carried out in four streams of the Chocancharava River and Ctalamochita River upper subbasins, Córdoba, Argentina (Fig. 1). These rivers are the main tributaries of Carcarañá River and belong to La Plata River basin. This fluvial system is one of the most important in the central region of Argentina since it supplies drinking water, irrigation and hydroelectric energy. Headwaters are in mountainous regions at about $2000 \mathrm{~m}$ a.s.1., where many small streams join to form the main collectors at foothills. Then they flow eastward through the pampean plain into the Carcarañá River. The Carcarañá River system has a highly dynamic and predictable hydrology with short and intense floods (Cantero et al., 1998). The rainy season, from October to March has a maximum of $725 \mathrm{~mm}$ and the minimum precipitation $(143 \mathrm{~mm})$ occurs between April and September (Capitanelli, 1979). Maximum temperature reaches $34^{\circ} \mathrm{C}$ in summer (December-March) and decreases to $-5^{\circ} \mathrm{C}$ in winter (June-September). Riparian vegetation of the study area, which is only partially shaded, changes in relation to the longitudinal gradient and its distribution is modified by human activities (Luti et al., 1979). Some native species of downstream zones, such as Acacia caven (Mol.) Mol., Geoffroea decorticans (Gill.) Burk. and Celtis tala Planchon, also occur at this altitude along the stream banks and in the adjacent areas (Cabido et al., 2003). In some reaches there are also exotic species of ornamental trees and shrubs.

Two reaches were selected in Piedras Blancas and Río de los Sauces streams (Table 1). Each of these streams is dammed by two small dams separated by nearly $100 \mathrm{~m}$. In both streams, one of the selected reaches was placed upstream the dams and the other downstream. Characteristics of the dams which are considered of importance in the assessment of the fluvial continuity (Reiser and Peacock, 1985; Bain and Stevenson, 1999) are summarized in Table 2. Floodgates of the second dam (in both streams) are closed only during summer (December-March) to fill up the deepest reservoir which is used as balneary by tourists. The gates are only opened when floods occur, phenomenon quite frequent in summer. A day after a flooding event, the gates are closed again to fill the reservoir. Additionally, two undammed streams were selected as controls: El Talita and Las Cañitas streams. In each stream, two sampling reaches were established (Table 1). Control sites were selected to be as similar as possible to impacted sites (dammed streams). 


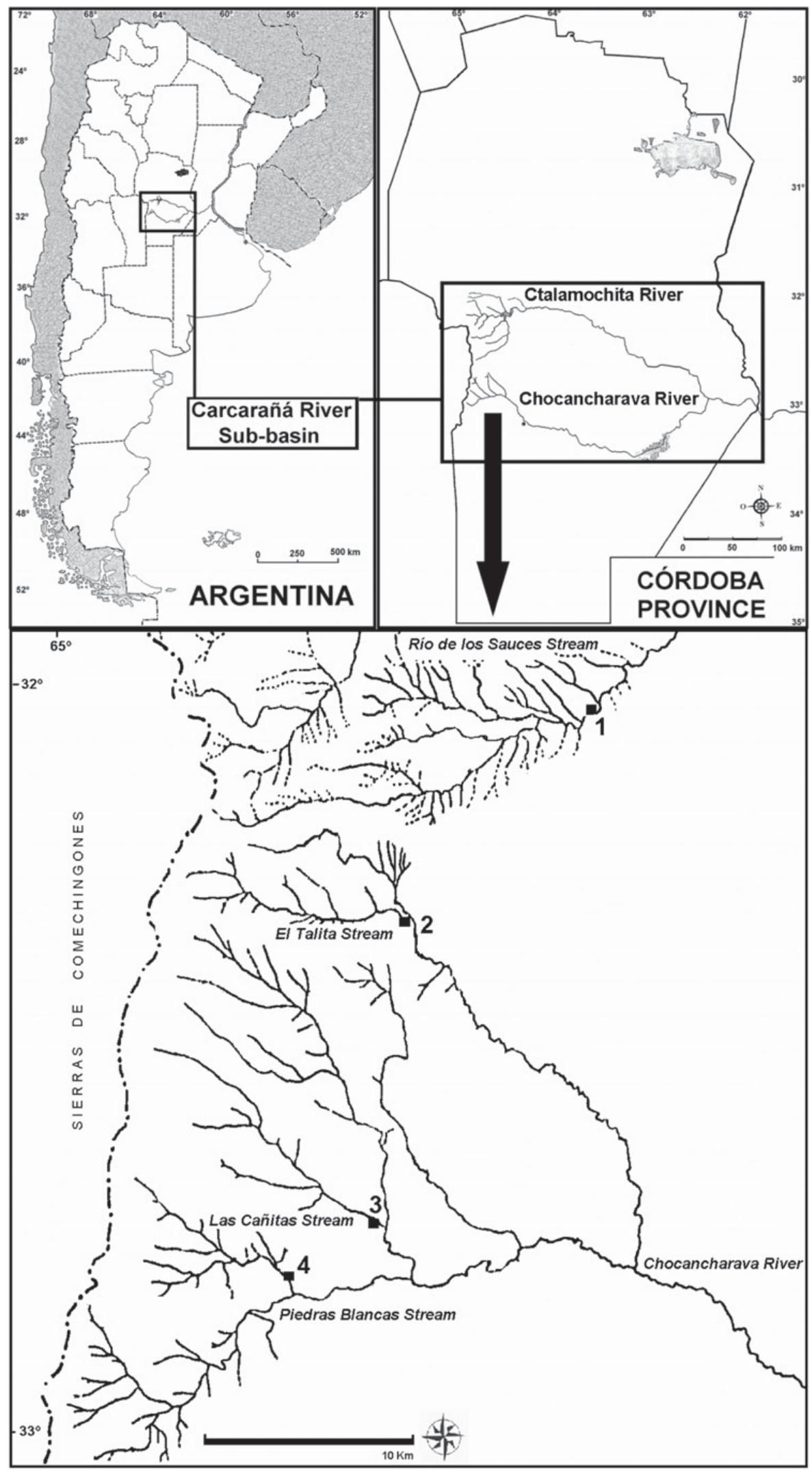

Fig. 1. Location of dammed (1: Río de los Sauces and 4: Piedras Blancas) and undammed streams (2: El Talita and 3: Las Cañitas) in Carcarañá River sub-basin, Córdoba, Argentina. 
Table 1. Location and environmental characterization of sampling reaches in the study streams. Piedras Blancas y Río de los Sauces are dammed streams and El Talita y las Cañitas are undammed.

\begin{tabular}{|c|c|c|c|c|c|c|c|c|}
\hline & \multicolumn{8}{|c|}{ Sampling reaches } \\
\hline & Piedras & Piedras & Río de los & Río de los & & & & \\
\hline & $\begin{array}{l}\text { Blancas } \\
\text { (upstream } \\
\text { dams) }\end{array}$ & $\begin{array}{c}\text { Blancas } \\
\text { (downstream } \\
\text { dams) }\end{array}$ & $\begin{array}{l}\text { Sauces } \\
\text { (upstream } \\
\text { dams) }\end{array}$ & $\begin{array}{c}\text { Sauces } \\
\text { (downstream } \\
\text { dams) }\end{array}$ & $\begin{array}{c}\text { El Talita } \\
\text { (Reach 1) }\end{array}$ & $\begin{array}{l}\text { El Talita } \\
\text { (Reach 2) }\end{array}$ & $\begin{array}{l}\text { Las Cañitas } \\
\text { (Reach 1) }\end{array}$ & $\begin{array}{l}\text { Las Cañitas } \\
\text { (Reach 2) }\end{array}$ \\
\hline Latitude (S) & $32^{\circ} 54^{\prime} 17^{\prime \prime}$ & $32^{\circ} 54^{\prime} 06^{\prime \prime}$ & $32^{\circ} 32^{\prime} 07^{\prime \prime}$ & $32^{\circ} 32^{\prime} 04^{\prime \prime}$ & $32^{\circ} 39^{\prime} 45^{\prime \prime}$ & $32^{\circ} 39^{\prime} 50^{\prime \prime}$ & $35^{\circ} 52^{\prime} 13^{\prime \prime}$ & $32^{\circ} 52^{\prime} 17^{\prime \prime}$ \\
\hline Longitude (W) & $64^{\circ} 50^{\prime} 40^{\prime \prime}$ & $64^{\circ} 50^{\prime} 30^{\prime \prime}$ & $64^{\circ} 35^{\prime} 43^{\prime \prime}$ & $64^{\circ} 35^{\prime} 21^{\prime \prime}$ & $64^{\circ} 44^{\prime} 47^{\prime \prime}$ & $64^{\circ} 44^{\prime} 43^{\prime \prime}$ & $64^{\circ} 45^{\prime} 35^{\prime \prime}$ & $64^{\circ} 45^{\prime} 38^{\prime \prime}$ \\
\hline Altitude (m a.s.1.) & 732 & 725 & 735 & 708 & 875 & 850 & 672 & 672 \\
\hline Stream order & \multicolumn{2}{|c|}{3} & \multicolumn{2}{|c|}{4} & \multicolumn{2}{|c|}{3} & \multicolumn{2}{|c|}{3} \\
\hline $\begin{array}{l}\text { Distance between } \\
\text { reaches }(\mathrm{m})\end{array}$ & \multicolumn{2}{|c|}{430} & \multicolumn{2}{|c|}{580} & \multicolumn{2}{|c|}{120} & \multicolumn{2}{|c|}{190} \\
\hline Reach size (m) & 20 & 18 & 30 & 20 & 40 & 60 & 50 & 50 \\
\hline Mean channel width (m) & 16 & 16 & 8 & 17 & 8 & 14 & 15 & 15 \\
\hline Vegetative cover $(\%)$ & $>95$ & $>95$ & $>95$ & $75-84$ & $>95$ & $>95$ & $75-84$ & $75-84$ \\
\hline $\begin{array}{l}\text { Consumption of trees and } \\
\text { shrubs by livestock }(\%)\end{array}$ & $0-5$ & $0-5$ & $0-5$ & $0-5$ & $0-5$ & $0-5$ & $5-25$ & $5-25$ \\
\hline $\begin{array}{l}\% \text { Bank with deep binding } \\
\text { root masses }\end{array}$ & $>85$ & $>85$ & $65-85$ & $<35$ & $>85$ & $65-85$ & $>85$ & $>85$ \\
\hline Management activities & Recreation & $\begin{array}{c}\text { Recreation - } \\
\text { Balneary }\end{array}$ & Recreation & $\begin{array}{c}\text { Recreation - } \\
\text { Balneary }\end{array}$ & $\begin{array}{c}\text { Recreation - } \\
\text { Livestock } \\
\text { grazing }\end{array}$ & $\begin{array}{c}\text { Recreation - } \\
\text { Livestock } \\
\text { grazing }\end{array}$ & $\begin{array}{c}\text { Agriculture - } \\
\text { Livestock } \\
\text { grazing }\end{array}$ & $\begin{array}{c}\text { Agriculture - } \\
\text { Livestock } \\
\text { grazing }\end{array}$ \\
\hline River channel pattern & Straight & Straight & Straight & Straight & Straight & Straight & Straight & Straight \\
\hline Dominant geomorphic units & Riffle-Run & Riffle - Run & Riffle-Run & Riffle - Run & Riffle - Run & Riffle-Run & Riffle-Run & Riffle-Run \\
\hline
\end{tabular}

a The percentage of bank with deep, binding root masses was assessed by visual estimation in both stream banks. All tree and shrub species were considered to provide such roots. In each bank, a transect was walked along the entire length of the study reach and root masses were assessed within a 2-m wide swath on each side of the transect. 
Table 2. Physical and structural characteristics of the small dams placed in Río de los Sauces and Piedras Blancas streams. Notice that two subsequent dams are placed in each stream (1 and 2). Length refers to the total distance of the dam across stream channel.

\begin{tabular}{|c|c|c|c|c|}
\hline & \multicolumn{4}{|c|}{ DAMS } \\
\hline & \multicolumn{2}{|c|}{ Río de los Sauces } & \multicolumn{2}{|c|}{ Piedras Blancas } \\
\hline & 1 & 2 & 1 & 2 \\
\hline Height $(\mathrm{m})^{\mathrm{a}}$ & 0.20 & 3.20 & 0.37 & 1.27 \\
\hline Depth of pond below dam $(\mathrm{m})^{\mathrm{a}}$ & 0.32 & 0.65 & 0.28 & 0.43 \\
\hline Gradient $^{\mathrm{a}}$ & $90^{\circ}$ & $35^{\circ}$ & $17^{\circ}$ & $48^{\circ}$ \\
\hline Width $(\mathrm{m})^{\mathrm{a}}$ & 3.00 & 0.52 & 0.65 & 0.47 \\
\hline Length (m) & 43.55 & 23.30 & 21.00 & 27.80 \\
\hline Number of floodgates & $\begin{array}{l}\text { without } \\
\text { floodgates }\end{array}$ & 2 & $\begin{array}{l}\text { without } \\
\text { floodgates }\end{array}$ & 5 \\
\hline Floodgates size (height - width, m) & - & $0.75-0.75$ & - & $1.00-0.90$ \\
\hline Impounded reach size $(\mathrm{m})$ & 300 & 35 & 240 & 30 \\
\hline Maximum depth in the reservoir (m) & 0.80 & $4.00^{\mathrm{b}}$ & 1.20 & $3.50^{\mathrm{b}}$ \\
\hline Distance between dams (m) & \multicolumn{2}{|c|}{80} & \multicolumn{2}{|c|}{110} \\
\hline
\end{tabular}

${ }^{a}$ Measurements taken according to Protocolo HIDRI (2006).

$\mathrm{b}$ These maximum depths are only registered when floodgates are closed.

\section{Experimental design}

The sampling scheme is adjusted to a mixed model nested ANOVA with four crossed fixed factors and two nested random factors. Two dammed streams (impacted streams) and two undammed streams (control streams) were selected. In each stream two different sampling reaches were selected being placed upstream and downstream the dam in impacted streams. Sampling was carried out in two different hydrological periods: high (March 2003) and low water period (July 2003). All reaches were sampled twice in each period because temporal replication is required to ensure seasonal comparisons in abundance (Underwood, 1994). In each sampling reach, three geomorphic units were selected: riffles, coarse substrate runs and fine substrate runs and dominant hydraulic units were identified in each of these geomorphic units. Three replicate surber samples were taken in each hydraulic unit following a stratified sampling design. A total of 288 benthic samples were collected $(4$ streams $\times 2$ reaches $\times 2$ hydrological periods $\times 2$ dates $\times 3$ hydraulic units $\times 3$ replicates).

\section{Field and laboratory methods}

In each hydraulic unit, substrate composition and flow type were visually assessed (Gordon et al., 1994) and assigned to a category proposed by Thomson et al. (2001). Maximum width and length of each hydraulic unit were measured and proportional abundance of macrophytes (submerged, floating and emergent), macroalgae and twigs and leaves were assessed. Current velocity and depth were measured with a Global Flow Probe FP101-FP201 for each sample (three times in each hydraulic unit). Conductivity, $\mathrm{pH}$, temperature and turbidity were measured with portable sensors on each sampling occasion and water chemical analyses were performed using the portable laboratory Hach 2000 and colorimetric analyses (Greenberg et al., 1992).
Benthic samples were taken using a Surber sampler $\left(0.09 \mathrm{~m}^{2}, 300 \mu \mathrm{m}\right.$ mesh size $)$ and invertebrates were preserved in $4 \%$ formaldehyde solution. At the laboratory, organisms were sorted, identified to the lowest possible taxonomic level, counted and kept in $70 \%$ ethanol. The identifications were made using available keys for Argentinian fauna (Domínguez and Fernández, 2009) and abundance was calculated as number of individuals per $\mathrm{m}^{2}$. After identification macroinvertebrates were assigned to a Functional Feeding Group (FFG) using available references (Berg, 1995; Lopretto and Tell, 1995; Merritt and Cummins, 1996, 2006; Callisto et al., 2001; Tomanova et al., 2006; Allan and Castillo, 2007).

\section{Data analyses}

Two-way ANOVAs were performed to examine differences in the physicochemical variables (water temperature, turbidity, $\mathrm{pH}$, conductivity, nitrate, nitrite, sulphate, phosphate, hardness and alkalinity) between dammed and undammed streams and between hydrological periods. The SNK test was used for a posteriori comparisons.

A detrended correspondence analysis (DCA) was carried out to analyze hydraulic unit distribution in dammed and undammed streams. This ordination technique was performed considering proportional abundance of hydraulic units in each sampling reach and date. A canonical correspondence analysis (CCA) (ter Braak, 1986) was performed with the total set of samples $(n=288)$ to explore macroinvertebrate distribution in reaches from impacted and control streams and associations of the assemblages with habitat variables. CCA were performed using the statistical package CANOCO version 4.02 (ter Braak and Smilauer, 1998). Abundance data were $\log _{10}(Y+1)$ transformed and a restricted Monte Carlo permutation test was performed (199 permutations) for determining the significance of eigenvalues derived from the CCA. Restricted permutations favoured the null 
model (completely random permutations) because benthic samples were collected in a special spatial structure (sampling scheme). Under this permutation scheme, only samples collected in the same stream and during the same hydrological period were permuted. The environmental variables substrate category and proportional abundance of bedrock and gravel were not included in the analysis because their variance inflation factors were higher than 20 (ter Braak and Smilauer, 1998).

TWINSPAN analysis was used to corroborate CCA results and then define more clearly groups of samples and characteristic macroinvertebrate assemblages. The analysis was performed including all samples collected in this study $(n=288)$. Indicator taxa for the groups were obtained using the Indicator Value Method (IndVal) proposed by Dufrene and Legendre (1997). This method combines measurements of the degree of specificity of a species to an ecological state, and its fidelity within that state. Species with a high specificity and high fidelity within a state will have a high indicator value. Good indicator species are thus those that are always present at sites in a given group and never occur in other groups (Dufrene and Legendre, 1997; McCune and Grace, 2002). Only taxa with significant $(p<0.05)$ indicator value (IV) $>25$ (i.e., species present in $>50 \%$ of the samples from one group and with a relative abundance in that group of $>50 \%$ (Dufrene and Legendre, 1997)) were retained. In addition, the sum of the taxa significant values provided by IndVal for each clustering level was retained as a criterion to determine when to stop the subdivision process since the method provide ecological significance to the groups of samples (Dufrene and Legendre, 1997). The IndVal method and TWINSPAN analysis were carried out using PC-Ord for Windows 4.25 (McCune and Mefford, 1999).

Nested ANOVAs were performed to assess dam effect on structure and function of benthic macroinvertebrate community. Six factors were included in the analysis: dam effect (control vs. impacted), reach effect (upstream $v s$. downstream dams), period effect (low water vs. high water), temporal replicate effect (two different dates in each period), habitat effect (riffle - coarse substrate run fine substrate run) and spatial replicate effect (three samples in each habitat). Date is a random factor nested within periods and spatial replicate is nested within habitat units. Different significant interaction terms in the analysis may indicate a dam effect (Underwood, 1994): Dam $\times$ Reach $\times$ Period $\times$ Habitat indicates spatial and temporal alteration in attributes due to dams, Dam $\times$ Reach $\times$ Period or Dam $\times$ Reach $\times$ Habitat indicate alterations at temporal or spatial scale respectively and finally Dam $\times$ Reach indicate that the differences in the attributes between reaches upstream and downstream the dam are significantly distinct to the differences in the same attributes between reaches in undammed streams.

Nested ANOVAs were performed for: total abundance, richness, diversity and evenness, abundance of FFGs and abundance of individual taxa including only taxa with frequency $>40 \%$ (22 taxa). To meet the assumptions of normality and homocedasticity, total abundance data were $\log _{10} Y$ transformed, diversity and evenness were $Y^{2}$ transformed, shredder abundance was $\log _{10}(Y+1)$ transformed, abundance of the remaining FFGs were ${ }^{3} \sqrt{ } Y$ transformed, abundance of 13 individual taxa were $\log _{10}(Y+1)$ transformed (Dugesiidae, Hydrachnidia, Americabaetis sp., Paracloeodes sp., Tricorythodes popayanicus Dominguez, 1982, Chimarra sp., Marilia sp., Simulium wolffhuegeli Enderlein, 1992, Polypedilum sp., Tanytarsus sp., Djalmabatista sp., Lopescladius sp., Cricotopus sp. 3) and abundance of 9 taxa were $\sqrt[3]{ } Y$ transformed (Naidinae, Camelobaetidius penai (Traver and Edmunds, 1968), Varipes sp., Caenis sp., Leptohyphes eximius, Eaton 1982, Coenagrionidae, Elmidae, Thienemannimyia sp., Corynoneura sp.).

In this paper, taxonomic richness is used instead of species richness (Malmquist et al., 2000) because not all the identifications were made at species level. Richness was measured considering the number of different taxa recorded and Shannon diversity and evenness were calculated using natural logarithms.

\section{Results}

The values of the physicochemical variables were standard for the mountain streams of the central region of Argentina and they did not indicate any alteration of water quality being among the recommended values for drinking water (Di.P.A.S., 1994). However, some variables presented differences between dammed and undammed streams according to the results of the twoway ANOVAs. Water temperature varied only due to seasonality $(F=41.64, p<0.0001)$. Average water temperature was $18.2{ }^{\circ} \mathrm{C}$ during the high water period and $10.7^{\circ} \mathrm{C}$ in the low water period. Turbidity, $\mathrm{pH}$, nitrate, nitrite, sulphate and phosphate did not show differences neither between stream types (turbidity: $F=0.94, p=$ 0.3449 ; pH: $F=4.28, p=0.0418$; nitrate: $F=0.49, p=$ 0.4966 ; nitrite: $F=1.16, p=0.3027$; sulphate: $F=0.17$, $p=0.6838$; phosphate: $F=0.42, p=0.5300)$ nor between hydrological periods (turbidity: $F=0.32, p=0.5788$; $\mathrm{pH}$ : $F=2.70, p=0.1159$; nitrate: $F=1.21, p=0.2921$; nitrite: $F=0.18, p=0.6789$; sulphate: $F=1.27, p=0.0677$; phosphate: $F=0.01, p=0.9187)$. Average $\mathrm{pH}$ value was 7.89 and ranged from 7.58 in El Talita stream during the high water period to 8.14 in Las Cañitas stream during the low water period. The minimum value of turbidity was $0.60 \mathrm{utm}$ in El Talita stream during the high water period whereas the maximum value was 1.67 in Río de los Sauces stream (see also Principe et al. (2007) for details of the physicochemical characterization of the streams considered in this study). In contrast, conductivity, hardness and alkalinity were different between dammed and undammed streams (conductivity: $F=13.75, \quad p=0.0014$; hardness: $F=8.30, p=0.0138$; alkalinity: $F=11.27, p=$ 0.0057). Conductivity was higher in dammed streams with an average value of $154.14 \mu \mathrm{S}$ compared to $93.50 \mu \mathrm{S}$ found in control streams. Hardness and alkalinity were also 


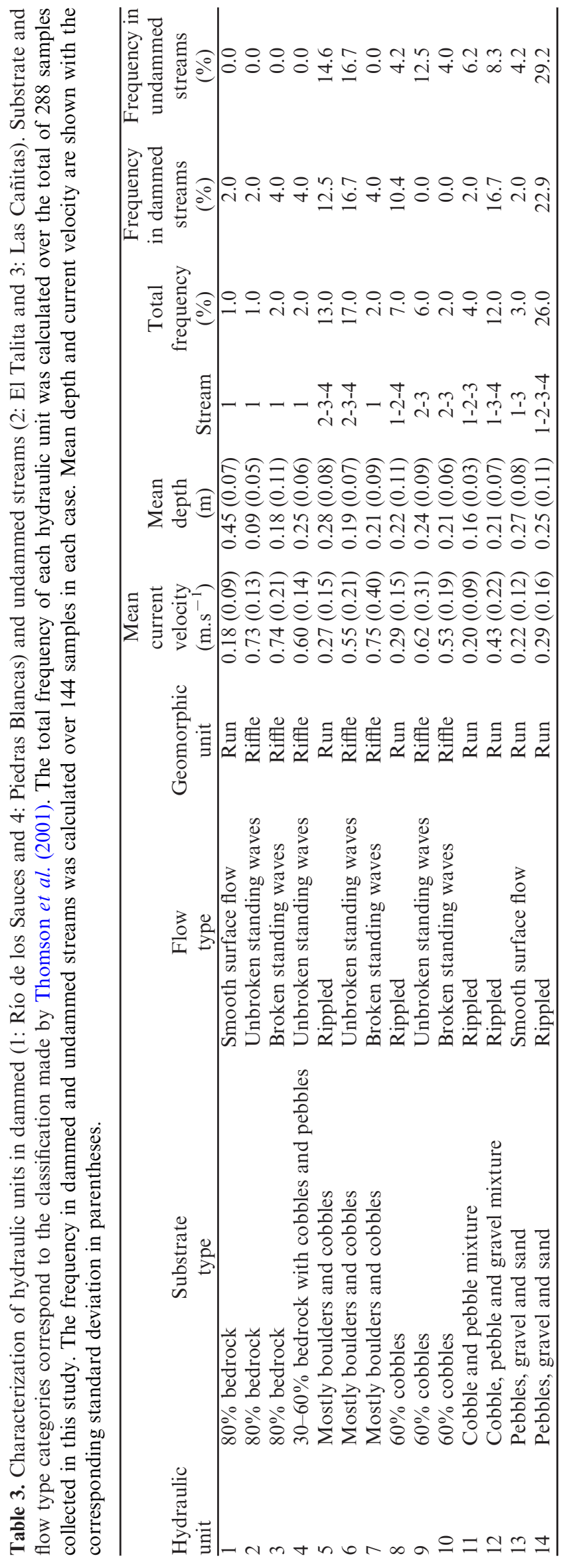

higher in impacted streams. Average harness was $51.68 \mathrm{mg} . \mathrm{L}^{-1}$ in impacted streams and $28.92 \mathrm{mg} . \mathrm{L}^{-1}$ in control streams whereas alkalinity were $74.58 \mathrm{mg} . \mathrm{L}^{-1}$ in dammed streams and $37.61 \mathrm{mg} . \mathrm{L}^{-1}$ in undammed streams.

Fourteen hydraulic units were registered (Table 3). The hydraulic unit 14 was the most frequent habitat unit and was registered in all reaches and both hydrological periods. The hydraulic units 5 and 6 were also quite frequent and were found in all streams except in the dammed stream Río de los Sauces. The hydraulic units 8 and 12 were found in runs and were more frequent in dammed than in control streams, but their total frequencies were less than $12 \%$. The hydraulic units 9 and 10 were exclusively found in control streams but with relatively low frequencies (12.5\% and 4\%, respectively). In Rio de los Sauces stream, five exclusive hydraulic units were found (Table 3). In this dammed stream a total of ten hydraulic units were registered whereas in the other impacted stream (Piedras Blancas) five units were found. In El Talita and Las Cañitas (control streams) seven and eight hydraulic units were registered respectively. In Piedras Blancas stream, hydraulic unit composition did not highly differ between reaches upstream and downstream the dam, but some differences were observed between reaches in Río de los Sauces stream since hydraulic units of finer substrate were dominant in the reach upstream the dams. Hydraulic unit composition did not differ between reaches of both control streams; but hydraulic units of coarser substrate were found in the upstream reach of El Talita stream during the low water period. The DCA performed to analyze the distribution of hydraulic units in sampling reaches showed segregation along both axes between the two dammed streams (Río de los Sauces and Piedras Blancas) (Fig. 2) and reaches of control streams (El Talita and Las Cañitas) scattered along the axis 2 without a clear grouping pattern. The first four ordination axes accounted for $36 \%$ of hydraulic unit proportional abundance (Eigenvalues: axis 1: 0.793; axis 2: 0.439; axis 3: 0.241; axis 4: 0.064).

The CCA grouped benthic samples mainly in relation to habitat units (Fig. 3). The first four ordination axes explained $83.2 \%$ of species-environment relation (Eigenvalues: axis 1: 0.399 ; axis 2: 0.159 ; axis 3 : 0.134 ; axis 4: 0.092) and restricted Monte Carlo permutation test showed that all axes were significant $(F=10.966$; $p$ value $=$ $0.005)$. Axis 1 separated samples mainly in relation to substrate and flow type. Samples collected in riffles were located on the right of the axis whereas samples collected in fine substrate runs were placed on the left (Fig. 3). The most important environmental variables in the ordination were substrate composition (cobbles, boulders and sand), flow type, current velocity and depth. Macrophytes, macroalgae and coarse organic matter such as twigs and leaves were mainly associated to the second axis. The CCA did not show a clear segregation among the hydraulic units identified within the geomorphic units (riffles, coarse substrate runs, and fine substrate runs). Hydraulic units 2, 3, $4,6,7,9$ and 10 found in riffles ordinated mostly on the right side of the plot, hydraulic units from fine substrate 


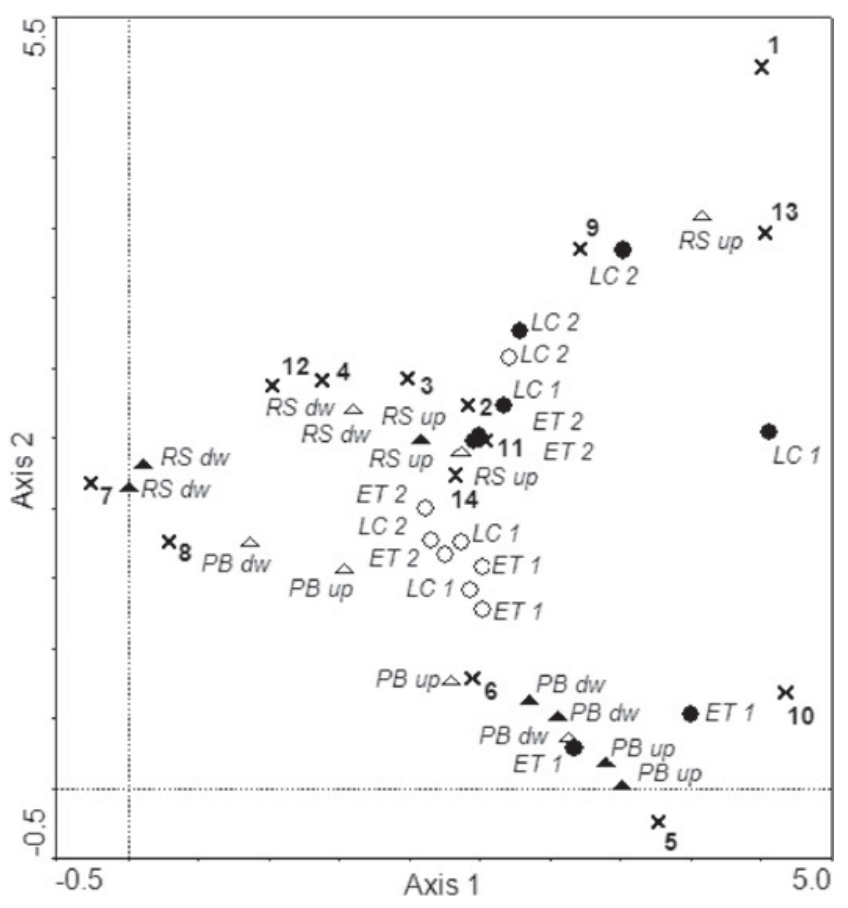

Fig. 2. DCA ordination of sampling reaches according to hydraulic unit composition (up: upstream reach and $d w$ : downstream reach in dammed streams. 1: upstream reach and 2: downstream reach in undammed stream). Crosses (1 to 14) represent hydraulic units, triangles represent dammed streams (RS: Río de los Sauces and PB: Piedras Blancas) and circles represent undammed streams (ET: El Talita and $L C$ : Las Cañitas). Open symbols correspond to the high water period and filled symbols to the low water period.

runs (13 and 14) ordinated on the left and hydraulic units from coarse substrate runs $(1,5,8,11$ and 12) presented a central location in the plot. Therefore, the CCA indicated that the main source of variation in the data set was the difference among geomorphic units whereas the different hydrological periods and the presence/absence of dams appeared to have a less important effect on the ordination.

TWINSPAN is presented with three hierarchical levels (Fig. 4) because the sum of the taxa significant values provided by IndVal was higher in the third hierarchical division. TWINSPAN analysis showed first a grouping tendency in relation to the presence/absence of dams. In the first hierarchical division one of the groups comprised $73 \%$ of samples collected in undammed streams and the other group included $86 \%$ of samples taken from dammed streams. The second division showed a grouping trend according to habitat type. Within the group of undammed streams, the second division separated habitats of coarse substrate from habitats characterized by fine substrate aggregating $91 \%$ of samples taken in coarse substrate habitats (riffles + coarse substrate runs) and in the other group $67 \%$ of samples from fine substrate habitats. Within the group of dammed streams, one of the groups generated by the second division comprised $70 \%$ of samples from coarse substrate habitats and the other included $78 \%$ the samples collected in fine substrate habitats. The third hierarchical division showed a grouping tendency in relation to streams but it was not as clear as in the previous divisions. TWINSPAN showed that habitat type was an important source of variation in the data set but the presence of dams revealed as the most important source of variation according to the results provided by this analysis. S. wolffhuegeli and Varipes sp. were indicador taxa of undammed streams with IV $>70 \%$ (Fig. 4). Dammed streams presented four indicator taxa with IV $>70 \%$ : Caenis sp., Thienemannimyia sp., Tanytarsus sp. and $T$. popayanicus. $S$. wolffhuegeli presented IV $=86 \%$ for coarse substrate habitats of undammed streams and Varipes sp. was the indicator taxon with the highest IV $(74.9 \%)$ for fine substrate habitats in these streams. In dammed streams, seven taxa were found to have significant IV for coarse substrate habitats but no taxon showed IV $>50 \%$. On the other hand, Tanytarsus sp. presented the highest IV for fine substrate habitats in these streams $(69.7 \%)$.

Nested ANOVAs showed effects of dams on the structure of macroinvertebrate community altering richness and diversity (Online Appendix 1, available at: www. limnology-journal.org/). The difference in these variables between upstream and downstream reaches in dammed streams was significantly higher than the difference of these variables between the consecutive reaches of undammed streams (Fig. 5). Both richness and diversity were higher in reaches downstream the dams. A single effect of habitat was detected on all measured structural variables (Online Appendix 1). The highest values of richness, diversity and evenness were found in coarse substrate habitats (riffles and runs) whereas the total abundance was highest in fine substrate runs. In addition, a single effect of the hydrological period was also found on abundance, richness and diversity. All these variables presented the maximum values during the low water period.

Nested ANOVAs showed effects of dams on the functional structure of the macroinvertebrate community changing the abundance of shredders and filtering-collectors (Online Appendix 2, available at: www. limnology-journal.org/). Changes in abundance of filtering-collectors showed dependence of the habitat and the hydrological period. The difference in shredder density between reaches of undammed streams was higher than the difference between upstream and downstream reaches of impacted streams (Fig. 6). The abundance of filteringcollectors was higher in riffles downstream the dams during the high water period but it was higher in fine substrate runs during the low water period (Fig. 7). A single effect of habitat was detected on the abundance of predators, shredders and gathering-collectors (Online Appendix 2). Shredder density was maximum in riffles and minimum in fine substrate runs, on the contrary, predators and gathering-collectors presented the highest density in fine substrate runs. In addition, a single effect of the hydrological period was observed on the abundance of predators and gathering-collectors, with the highest values during the low water period. 


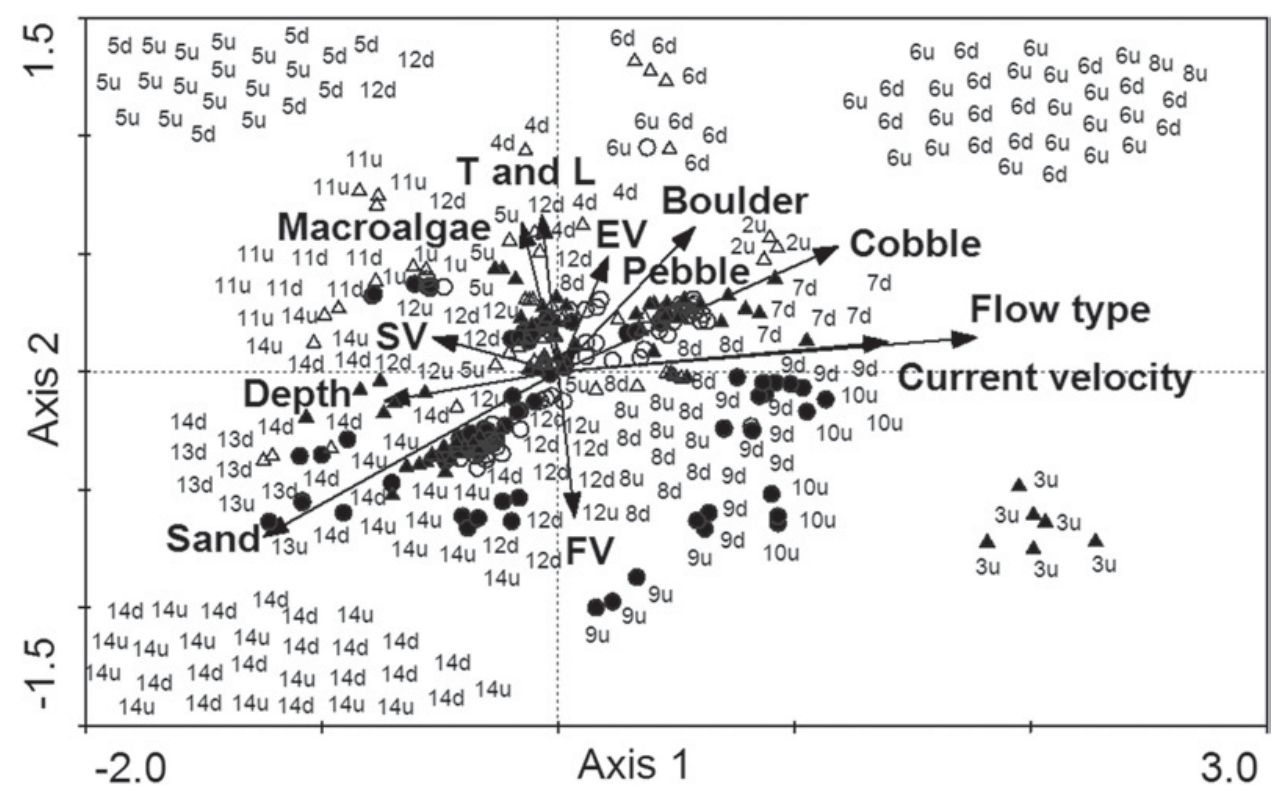

Fig. 3. CCA ordination of benthic samples according to macroinvertebrate composition. Triangles represent dammed streams and circles represent undammed streams. Blank symbols correspond to the high water period and filled symbols to the low water period. Numbers 1 to 14 correspond to hydraulic units and letters $u$ and $d$ represent upstream reaches and downstream reaches respectively. In environmental variables $\mathrm{T}$ and $\mathrm{L}$ : twigs and leaves, FV: floating vegetation, EV: emergent vegetation and SV: submerged vegetation.

Nested ANOVAs showed effects of dams on the abundance of five macroinvertebrate taxa (Online Appendix 3, available at: www.limnology-journal.org/). The difference in the abundance of Marilia sp., Thienemannimyia sp. and Cricotopus sp. 3 between upstream and downstream reaches of dammed streams was higher than the difference between reaches of undammed streams (Fig. 8). An increase in density of these taxa was observed in reaches downstream the dams. On the other hand, the difference in Dugesiidae and Polypedilum sp. densities between reaches of control streams was higher than the difference between reaches of dammed streams. A single effect of habitat was observed on the abundance of 18 taxa (Online Appendix 3). Dugesiidae, C. penai, L. eximius, Chimarra sp., Elmidae, S. wolffhuegeli, Polypedilum sp. and Cricotopus sp. 3 showed the maximum abundances in riffles whereas Americabaetis sp., Paracloedodes sp., Varipes sp., T. popayanicus, Djalmabatista sp. and Thienemannimyia sp. showed the maximum densities in fine substrate runs. The density of Corynoneura sp. was higher in coarse substrate runs, Coenagrionidae showed the maximum abundance in coarse substrate habitats (riffles and runs) and Caenis sp. and Lopescladius sp. presented their maximum density in runs (fine and coarse substrate). Moreover, a single effect of the hydrological period was detected on the abundance of 10 taxa and a single effect of dams was observed on 11 taxa (Online Appendix 3). Of the 10 taxa only $C$. penai, Varipes sp. and Marilia sp. presented the highest density during the high water period. In relation to the single effect of dams Naidinae, Hydrachnidia, Varipes sp., Paracloeodes sp. and Lopescladius sp. presented higher densities in control streams whereas $C$. penai, Caenis sp.,
Coenagrionidae, Elmidae, Americabaetis sp. y Djalmabatista sp. presented higher densities in dammed streams. These results agree with those obtained by TWINSPAN which separated dammed streams from undammed streams.

\section{Discussion}

The findings of this study showed that small dams impacted invertebrate communities although hydraulic habitats were not affected. Fourteen hydraulic units were identified, but important variation in hydraulic unit composition was not detected neither between upstream and downstream reaches in dammed streams nor between impacted and control streams. Some exclusive hydraulic units were registered in one of the dammed streams but they presented low frequency. DCA ordination did not showed segregation in relation to the presence of the dams since reaches of impacted streams were scattered in the analysis and reaches of control streams did not show a clear grouping pattern. Therefore differences in hydraulic unit composition were not observed between dammed and undammed streams. Hydraulic unit distribution would respond more to the typical dynamic of the fluvial hydrology (Rosgen, 1996) than to an effect of dam presence. Some studies have found important variations in habitat composition between reaches of a river specially when the river channel pattern changes (Thomson et al., 2001) and others have detected notable differences in abundance and distribution of mesohabitats between non-impacted reaches in a stretch of only $2 \mathrm{~km}$ (Tickner et al., 2000). 


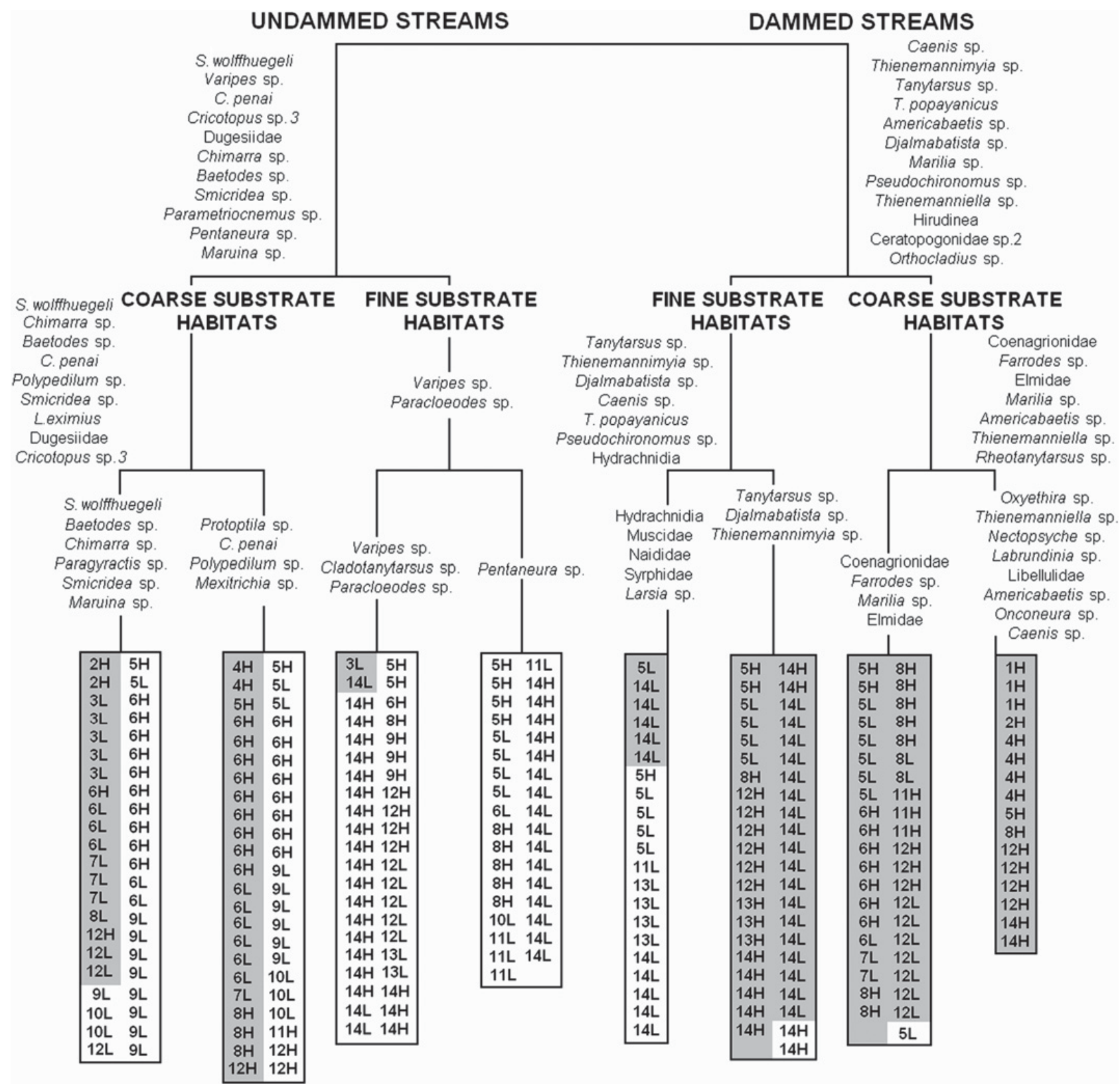

Fig. 4. TWINSPAN classification of benthic samples collected in dammed (grey) and undammed streams (white). Numbers 1 to 14 correspond to hydraulic units and letters $H$ and $L$ correspond to high and low water period respectively. Indicator taxa were obtained using the IndVal method. Only taxa with significant IV $>25 \%$ were retained.

These findings demonstrate the highly variable condition of fluvial habitats in natural systems. On the other hand, some studies have found that stream geomorphology was not highly altered by small dams probably due to the extent of geologic control at study sites (Ambers, 2007; Skalak et al., 2009). Additionally, the results obtained in this study in relation to habitat distribution may indicate that habitat quality would offer suitable physical conditions to biodiversity conservation and maintenance of macroinvertebrate assemblages not only in control streams but also in dammed streams.

The CCA showed that habitat type was the most important source of variation of faunal composition being substrate composition, flow type, current velocity and depth the key environmental variables affecting the ordination. It has already been demonstrated that macroinvertebrate assemblages are strongly conditioned by substrate variability and hydraulic variables (Rempel et al., 2000; Thomson et al., 2003). Although some hydraulic units were separated in the CCA, others found in the same geomorphic unit were not clearly segregated. It has already been reported that contrasting hydraulic units may present quite similar macroinvertebrate assemblages (Principe et al., 2007). Moreover, TWINSPAN analysis allowed identifying only two different groups in relation to habitat units (coarse and fine substrate habitats). 

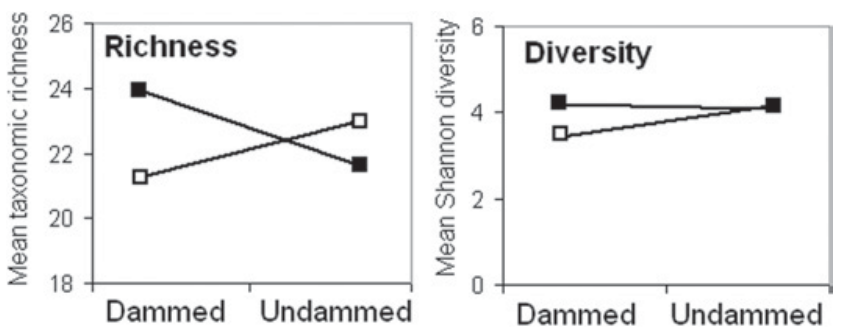

Fig. 5. Effect of the significant interaction term Dam $\times$ Reach on richness and diversity of the benthic macroinvertebrate community according to the results of nested ANOVAs. Blank symbols correspond to the reach upstream the dams in impacted streams and reach 1 in control streams whereas filled symbols correspond to the reach downstream the dams in impacted streams and the reach 2 in control streams.

These results suggest that not all the identified hydraulic units may be functioning as functional habitats (sensu Harper et al., 1998) since they would not be all characterized by a distinctive macroinvertebrate assemblage. On the other hand, the results showed a clear segregation between assemblages of riffles and runs and it was also possible to differentiate assemblages of coarse and fine substrate runs. So, the CCA indicated that the main source of variation was the difference among geomorphic units whereas the different hydrological periods and the presence/absence of dams appear to have a less important effect on the ordination.

Results obtained with nested ANOVAs allow to identify some dam effects on the structure and function of the macroinvertebrate community. Gumiero and Salmoiraghi (1998) analyzed the effect of a dam following a design similar to that used in this study and they found a significant reduction of abundance and biomass of invertebrates in habitats composed mainly by cobbles. In this study changes in macroinvertebrate density by effect of the dam were not observed, but richness and diversity increased in reaches downstream the dams. It has been reported that large dams generate a reduction of richness and diversity in downstream reaches due to the elimination of sensitive species that respond to habitat alteration (Ward, 1992; Allan and Castillo, 2007). However in this study important habitat alteration was not registered since habitat units did not highly differ between control and impacted streams and on the contrary to the results observed for large dams, taxonomic richness and diversity increased in downstream reaches. Some river restoration strategies involve the construction of small transversal barriers on the riverbed in order to recover or increase habitat heterogeneity (Rosgen, 1997, 2006; FISRWG, 1998). These barriers are similar to the small dams of the study streams and although they may become potential barriers to some species, they may also generate novel habitats or improve habitat quality favouring species diversity (FISRWG, 1998).

Nested ANOVAs also showed changes in trophic structure by effect of the dams. In this study, density of filtering-collectors increased in downstream reaches and

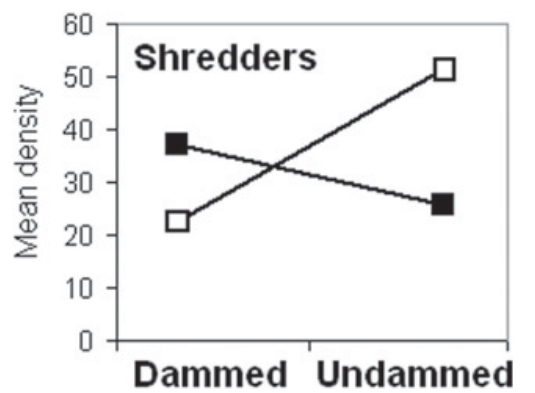

Fig. 6. Effect of the significant interaction term Dam $\times$ Reach on the abundance of shredders according to the results of nested ANOVAs. Blank symbols correspond to the reach upstream the dams in impacted streams and reach 1 in control streams whereas filled symbols correspond to the reach downstream the dams in impacted streams and the reach 2 in control streams.

this change depended on the habitat and the hydrological period. Englund and Malmqvist (1996) and Fleituch (2003) have reported that FFGs respond differently to the alterations generated by the presence of dams. Vallania and Corigliano (2007) found higher abundance of filtering-collectors in reaches downstream the dams and they also reported changes in the density of the other FFGs. In general, it has been confirmed the increase of filterers (mainly hydropsychids and simulids) downstream the dams due to the discharge of fine particulate organic matter and planktonic algae that constitute the main food resource of filtering-collectors (Ward and Stanford, 1995).

Although an effect of the interaction Dam $\times$ Reach was detected on the abundance of shredders, the difference between reaches of control streams was higher than the difference between upstream and downstream reaches in impacted streams. These differences observed between reaches of control streams may be interpreted taking into account the patch dynamic concept (Townsend, 1989) and the great heterogeneity that characterize lotic ecosystems (Palmer and Poff, 1997). The stretch of control streams that includes upstream and downstream reaches is highly heterogeneous whereas in impacted streams this stretch is homogenized by the reservoir formed by the dams. Therefore, the evidence suggests that this homogeneity may affect the colonization by shredders of habitats with coarse organic matter.

Nested ANOVAs indicated a single dam effect on the abundance of most of the 22 taxa evaluated. This agree with the results obtained by TWINSPAN which separated impacted streams from control streams and did not show differences between upstream and downstream reaches in both stream types. Additionally, conductivity, hardness and alkalinity were different between dammed and undammed streams. Although reaches downstream the dams did not highly differ from upstream reaches, the whole dammed stretch in both impacted streams was different from control stretches. This would indicate that dams alter not only downstream reaches but also the upstream ones which are close to the tail waters of the reservoir (Evans et al., 2007). Important changes due to dams were not 
HIGH WATER PERIOD
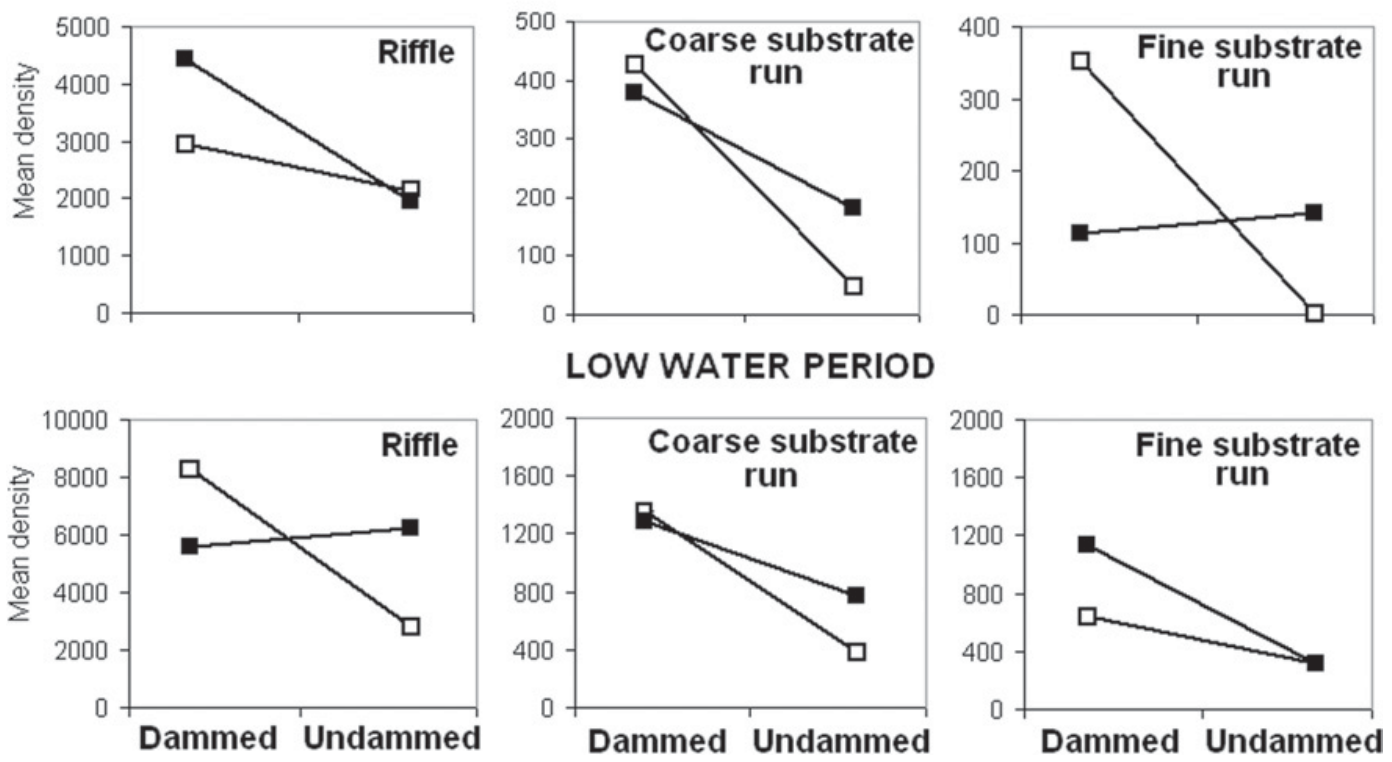

Fig. 7. Effect of the significant interaction term Dam $\times$ Reach $\times$ Habitat $\times$ Period on the abundance of filtering-collectors according to the results of nested ANOVAs. Blank symbols correspond to the reach upstream the dams in impacted streams and reach 1 in control streams whereas filled symbols correspond to the reach downstream the dams in impacted streams and the reach 2 in control streams.
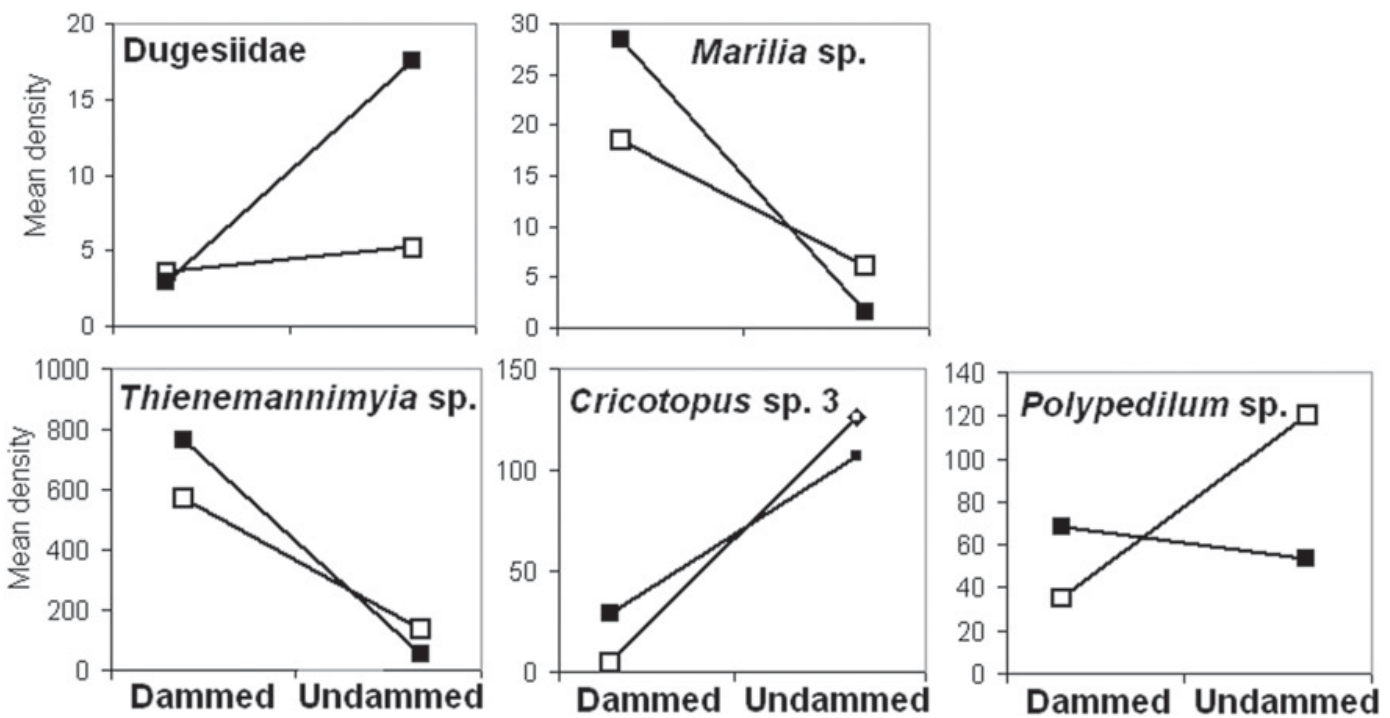

Fig. 8. Effect of the significant interaction term Dam $\times$ Reach on the abundance of Dugesiidae, Marilia sp., Polypedilum sp., Thienemennimyia sp. and Cricotopus sp. 3 according to the results of nested ANOVAs. Blank symbols correspond to the reach upstream the dams in impacted streams and reach 1 in control streams whereas filled symbols correspond to the reach downstream the dams in impacted streams and the reach 2 in control streams.

observed in assemblage composition since the ordination analysis did not group samples in relation to the presence of the dams. In the ordination, the main source of variation was the fluvial habitat which did not show differences between impacted and control streams. Some authors have reported changes in taxonomic composition of the benthic invertebrate community due to alteration of fluvial habitats by effect of large dams (Gumiero and Salmoiraghi, 1998; Growns and Growns, 2001; Lessard and Hayes, 2003) but others found a relatively minor impact of small dams on the river biota in downstream reaches (Sharma et al., 2005; Ambers, 2007).

Although in this study differences in taxonomic composition between upstream and downstream reaches 
were not detected, nested ANOVAs showed some changes in richness and diversity, in the density of filteringcollectors and shredders and in the abundance of some species. These results would indicate that small dams have only a moderate impact compared to the documented impact of large dams. In addition, Ambers (2007) pointed out that the impact of small dams declines to negligible ecological levels few kilometers downstream. Large dams produce notable changes in benthic communities by elimination of habitats, flow regulation and alteration of the thermal regime (Armitage and Pardo, 1995; Benstead et al., 1999; Growns and Growns, 2001; Lessard and Hayes, 2003; Grubbs and Taylor, 2004). As a result, sensitive species disappear and the density of eurioc species increases (Ward, 1992). On the other hand, small dams may constitute barriers that disrupt connectivity of lotic ecosystems and may generate discontinuities in the structure and function of some aquatic communities such as fish fauna (Meixler and Bain, 2003; Saila et al., 2005). With regard to macroinvertebrates, the patterns of each population in drift and colonization processes, the continuity of the riparian structure and the discharge of phytoplanktonic algae downstream the dams may be some factors determining the ecological changes produced by small impoundments. A food web perspective should also be taken into account since populations of any species depend critically on how their resources, prey and potential predators also respond to environmental change (Power et al., 1996). Further research involving these topics should be carried out to explore the mechanisms explaining the patterns observed in this study.

Acknowledgements. Many people helped with field work: H. Principe, M. Corigliano, J. Ison, L. Ornella, A. Principe, F. Principe, M. Gualdoni, A. Oberto, G. Raffaini, M. Boccolini, E. Medeot, C. Duarte, D. Gómez, V. Angeli, F. Costa and I. Simone. Special thanks to M. Gualdoni, A. Oberto and M. Corigliano for their useful comments on the manuscript and to D. Gomez for statistical advice. This study was supported by Secretaría de Ciencia y Técnica (UNRC) and by a fellowship gave to the author by Consejo Nacional de Investigaciones Científicas y Técnicas (CONICET), Argentina. I also thank R. Albariño for English corrections and improvements to the manuscript and two anonymous reviewers for their valuable comments and suggestions.

\section{References}

Allan J.D. and Castillo M.M., 2007. Stream ecology - Structure and function of running waters, Springer, Dordrecht.

Ambers R.K.R., 2007. Effects of a small, century-old dam on a second order stream in the Virginia piedmont. Southeast. Geogr., 47, 181-201.

American Rivers, Friends of the Earth and Trout Unlimited, 1999. Dam removal success stories: restoring rivers through selective removal of dams that don't make sense, American Rivers, Friends of the Earth and Trout Unlimited, Washington.
Armitage P.D. and Pardo I., 1995. Impact assessment of regulation at the reach level using macroinvertebrate information from mesohabitats. Regul. Rivers Res. Manag., 10, 147-158.

Bain M.B. and Stevenson N.J., 1999. Aquatic habitat assessment: common methods, American Fisheries Society, Bethesda.

Baxter R.M., 1977. Environmental effects of dams and impoundments. Annu. Rev. Ecol. Syst., 8, 255-283.

Benstead J.P., March J.G., Pringle C. and Scatena F., 1999. Effects of a low-head dam and water abstraction on migratory tropical stream biota. Ecol. Appl., 9, 656-668.

Berg M.B., 1995. Larval food and feeding behaviour. In: Armitage P.D., Cranston P.S. and Pinder L.C.V. (eds.), The Chironomidae - The biology and ecology of non-biting midges, Chapman and Hall, London, 136-168.

Brandt S.A., 2000. Classification of geomorphological effects downstream of dams. Catena, 40, 375-401.

Bredenhand E. and Samways M.J., 2009. Impact of a dam on benthic macroinvertebrates in a small river in a biodiversity hotspot: Cape Floristic Region, South Africa. J. Insect Conserv., 13, 297-307.

Brittain J.E. and L'Abee-Lund J.H., 1995. The environmental effects of dams and strategies for reducing their impact. In: Santbergen L. and Van Westen C. (eds.), Reservoirs in river basin development, Balkema, Rotterdam, 129-138.

Cabido D., Cabido M., Garre S.M., Gorgas J.A., Miatello R., Rambaldi S., Ravelo A. and Tassile J.L., 2003. Regiones Naturales de la Provincia de Córdoba, Serie C, Publicaciones Técnicas, Agencia Córdoba, Dirección de Ambiente, Córdoba.

Callisto M., Moreno P. and Barbosa F.A.R., 2001. Habitat diversity and benthic functional trophic groups at Serra do Cipó, Southeast Brazil. Rev. Bras. Biol., 61, 259-266.

Cantero G.A., Cantu M.P., Cisneros J.M., Cantero J.J., Blarasin M., Degioanni A., Gonzalez J., Becerra V., Gil H., De Prada J., Degiovanni S., Cholaky C., Villegas M., Cabrera A. and Eric C., 1998. Las tierras y aguas del sur de Córdoba: propuestas para un manejo sustentable, Universidad Nacional de Río Cuarto, Córdoba.

Capitanelli R.G., 1979. Clima. In: Vázquez J.V., Miatello R.A. and Roqué M.E. (dirs.), Geografía Física de la Provincia de Córdoba, Editorial Boldt, Buenos Aires, 45-138.

Corigliano M.C., 1994. El efecto de los embalses sobre la fauna planctónica y bentónica del río Ctalamochita (Tercero), (Córdoba, Argentina). Rev. UNRC, 14, 23-38.

Di.P.A.S., 1994. Normas provinciales de calidad y control de aguas para bebida, Res. 608/93, Vol. 1, Sistema Provincial de Control de Calidad, Córdoba.

Domínguez E. and Fernández H.R., 2009. Macroinvertebrados bentónicos sudamericanos - Sistemática y biología, Fundación Miguel Lillo, Tucumán.

Dufrene M. and Legendre P., 1997. Species assemblages and indicator species: the need for a flexible asymmetrical approach. Ecol. Monogr., 67, 345-366.

Englund G. and Malmqvist B., 1996. Effects of flow regulations, habitat area and isolation on the macroinvertebrates fauna of rapids in north Swedish Rivers. Regul. Rivers Res. Manag., $12,433-445$.

Evans J.E., Huxley J.M. and Vincent R.K., 2007. Upstream channel changes following dam construction and removal using a GIS/remote sensing approach. J. Am. Water Resour. Assoc., 43, 683-697. 
FISRWG, 1998. Stream Corridor Restoration: Principles, Processes, and Practices, Federal Interagency Stream Restoration Working Group, USA.

Fleituch T., 2003. Structure and functional organization of benthic invertebrates in a regulated stream. Int. Rev. Hydrobiol., 88, 332-344.

Gordon N.D., Mcmahon T.A. and Finlayson B.L., 1994. Stream hydrology, an introduction for ecologists, Wiley and Sons, New York.

Greenberg A.E., Clesceri L.S. and Eaton A.D., 1992. Standard methods for the examination of water and wastewater, American Public Health Association, Washington.

Growns I.O. and Growns J.E., 2001. Ecological effects of flow regulation on macroinvertebrate and periphytic diatom assemblages in the Hawkesbury - Nepean River, Australia. Regul. Rivers Res. Manag., 17, 275-293.

Grubbs S.A. and Taylor J.M., 2004. The influence of flow impoundment and river regulation on the distribution of riverine macroinvertebrates at Mammoth Cave National Park, Kentucky, U.S.A. Hydrobiol., 520, 19-28.

Gumiero B. and Salmoiraghi G., 1998. Influence of an impoundment on benthic macroinvertebrate habitat utilization. Verh Internat. Verein. Limnol., 26, 2063-2069.

Harper D.M., Smith C., Kemp J. and Crosa G., 1998. The use of 'functional habitats' in the conservation, management and rehabilitation of rivers. In: Bretschko G. and Helesic J. (eds.), Advances in river bottom ecology, Backhuys Publishers, Leiden, 315-326.

Hart D.D., Johnson T.E., Bushaw-Newton K.L., Horwitz R.J., Bednarek A.T., Charles D.F., Kreeger D.A. and Velinsky D.J., 2002. Dam removal: Challenges and opportunities for ecological research and river restoration. BioScience, 52, 669-681.

Lessard J.L. and Hayes D.B., 2003. Effects of elevated water temperature on fish and macroinvertebrate communities below small dams. River Res. Appl., 19, 721732.

Lopretto E.C. and Tell G., 1995. Ecosistemas de aguas continentales - Metodologías para su studio, Volumes II and III, Ediciones Sur, La Plata.

Lucas M.C., Bubb D.H., Jang M., Ha K. and Masters J.E.G., 2008. Availability of and access to critical habitats in regulated rivers: effects of low-head barriers on threatened lampreys. Freshw. Biol., 54, 621-634.

Luti R., Bertran M.A., Galera F.M., Müller N., Berzal M., Nores M., Herrera M.A. and Barrera J.C., 1979. Vegetación. In: Vázquez J.V., Miatello R.A. and Roqué M.E. (dirs.), Geografía Física de la Provincia de Córdoba, Editorial Boldt, Buenos Aires, 318-321.

Malmquist H.L., Antonsson T., Gudbergsson G., Skülason S. and Snorrason S.S., 2000. Biodiversity of macroinvertebrates on rocky substrate in the surf zone of iceland lakes. Verh. Internat. Verein. Limnol., 27, 121-127.

Maloney K.O., Dodd H.R., Butler S.E. and Wahl D.H., 2008. Changes in macroinvertebrate and fish assemblages in a medium-sized river following a breach of a low head-dam. Freshw. Biol., 53, 1055-1068.

McCune B. and Grace J.B., 2002. Analysis of Ecological Communities, MjM Software, Oregon.

McCune B. and Mefford M.J., 1999. Multivariate Analysis of Ecological Data, Version 4.25, MjM Software, Gleneden Beach.
Meixler M. and Bain M., 2003. Habitat fragmentation mapping, Department of Natural Resources, Cornell University, Available online at: http://hydroeco.cfe.cornell.edu/habfrag. htm.

Merritt R.W. and Cummins K.W., 1996. An introduction to the aquatic insects of North America, Third edn., Kendall/Hunt, Dubuque.

Merritt R.W. and Cummins K.W., 2006. Trophic relationships of macroinvertebrates. In: Hauer F.R. and Lamberti G.A. (eds.), Methods in stream ecology, Second edn., Academic Press, San Diego, 585-601.

Palmer M.A. and Poff N.L., 1997. Heterogeneity in streams. The influence of environmental heterogeneity on patterns and processes in streams. J. North Am. Benthol. Soc., 16, 169-173.

Poff N.L. and Hart D.D., 2002. How dams vary and why it matters for the emerging science of dam removal. BioScience, $52,659-668$.

Power M.E., Dietrich W.E. and Finlay J.C., 1996. Dams and downstream biodiversity: potential food web consequences of hydrologic and geomorphic change. Environ. Manag., 20, 887-895.

Principe R.E., Raffaini G.B., Gualdoni C.M., Oberto A.M. and Corigliano M.C., 2007. Do hydraulic units define macroinvertebrate assemblages in mountain streams of central Argentina? Limnologica, 37, 323-336.

Protocolo HIDRI, 2006. Protocolo para la valoración de la calidad hidromorfológica de los rios, Agència Catalana de l'Aigua, Available online at: http://aca-eb.gencat.cat/aca/ documents/ca/directiva_marc/manual_hidri_cas.pdf.

Reiser D.W. and Peacock R.T., 1985. A technique for assessing upstream fish passage problems at small-scale hydropower developments. In: Olson F.W., White R.G. and Hamre R.H. (eds.), Symposium on small hydropower and fisheries, American Fisheries Society, Bethesda, 423-432.

Rempel L.L., Richardson J.S. and Healey M.C., 2000. Macroinvertebrate community structure along gradients of hydraulic and sedimentary conditions in a large, gravel-bed river. Freshw. Biol., 45, 57-63.

Rosgen D.L., 1996. Applied River Morphology-Wildland Hydrology Books, Pagosa Springs, Ft. Collins.

Rosgen D.L., 1997. A geomorphological approach to restoration of incised rivers. In: Wang S.S.Y., Langendoen E.J. and Shields Jr F.D. (eds.), Proceedings of the Conference on Management of Landscapes Disturbed by Channel Incision.

Rosgen D.L., 2006. The Cross-Vane, W-Weir and J-Hook Vane structures and their description, design and application for stream stabilization and river restoration, Wildland Hydrology, Inc. Ft. Collins, Colorado, Available online at: http://www.wildlandhydrology.com/assets/The_Cross_Vane_ W-Weir_and_J-Hook_Structures_Paper_Updated_2006.pdf.

Saila S.B., Poyer D. and Aube D., 2005. Small dams and habitat quality in low order streams, Wood-Pawcatuck Watershed Association, Hope Valley.

Sharma C.M., Sharma S., Borgstrom R. and Bryceson I., 2005. Impacts of a small dam on macroinvertebrates: A case study in the Tinau River, Nepal. Aquat. Ecosyst. Health Manag., 8, 267-275.

Skalak K., Pizzuto J. and Hart D.D., 2009. Influence of small dams on downstream channel characteristics in Pennsylvania and Maryland: implications for the long-term geomorphic effects of dam removal. J. Am. Water Resour. Assoc., 45, 97109. 
Ter Braak C.J.F., 1986. Canonical correspondence analysis: a new eigenvector technique for multivariate direct gradient analysis. Ecology, 67, 1167-1179.

Ter Braak C.J.F. and Smilauer P., 1998. CANOCO Reference Manual and User's Guide to Canoco for Windows: Software for Canonical Community Ordination (version 4), Microcomputer Power, Ithaca, New York.

Thomson J.R., Taylor M.P., Fryirs K.A. and Brierley G.J., 2001. A geomorphological framework for river characterization and habitat assessment. Aquat. Conserv., 11, 373-389.

Thomson J.R., Taylor M.P. and Brierley G.J., 2003. Are River Styles ecologically meaningful? A test of the ecological significance of a geomorphic river characterization scheme. Aquat. Conserv., 14, 25-48.

Tickner D., Armitage P.D., Bickerton M.A. and Hall K.A., 2000. Assessing stream quality using information on mesohabitat distribution and character. Aquat. Conserv., 10, 170-196.

Tomanova S., Goitia E. and Helešic J., 2006. Trophic levels and functional feeding groups of macroinvertebrates in neotropical streams. Hydrobiol., 556, 251-264.

Townsend C.R., 1989. The patch dynamics concepts of stream community ecology. J. North Am. Benthol. Soc., 8, 36-50.

Underwood A.J., 1994. Spatial and temporal problems with monitoring. In: Calow P. and Petts E. (eds.), The Handbook of River, Blackwell, Oxford, 182-204.
Vallania A.E., Medina A.I. and Sosa M.E., 1998. Estructura de la comunidad de Trichoptera en un arroyo regulado de la provincia de San Luis, Argentina. Rev. Soc. Entomol. Argent., 57, 7-11.

Vallania A.E. and Corigliano M.C., 2007. The effect of regulation caused by a dam on the distribution of the functional feeding groups of the benthos in the sub basin of the Grande River (San Luis, Argentina). Environ. Monit. Assess., 124, 201-209.

Ward J.V., 1982. Ecological aspects of stream regulation: responses in downstream lotic reaches. Water Pollut. Manag. Rev. (New Delhi), 2, 1-26.

Ward J.V., 1992. Aquatic insect ecology - Biology and habitat, Willey and Sons, New York.

Ward J.V. and Stanford J.A., 1979. Ecological factors controlling stream zoobenthos with emphasis on thermal modification of regulated streams. In: Ward J.V. and Stanford J.A. (eds.), The ecology of regulated streams, Plenum Publishing Corporation, New York, 35-55.

Ward J.V. and Stanford J.A., 1995. The serial discontinuity concept: Extending the model to floodplain rivers. Regul. Rivers: Res. Manag., 11, 105-119.

Zeilhofera P. and de Moura R.M., 2009. Hydrological changes in the northern Pantanal caused by the Manso dam: Impact analysis and suggestions for mitigation. Ecol. Eng., 35, 105117. 